\title{
KLIMAPOLITIK
}

\section{Rygter, røgslør og relationer på COP15}

\section{JANNE BJERRE CHRISTENSEN}

„Når vi spørger ind til, hvad der foregår, får vi hele tiden at vide, at det her bare er 'spillet'. Det er helt forventeligt. Det skal de jo sige. Men problemet er: Spillet er $j o$ virkeligheden her. Det er ikke to forskellige ting. Hvad er jeres nøgterne vurdering af, hvad der foregår?" Margrethe Vestager ser sig frustreret om i lokalet, hvor en gruppe danske ngo-lobbyister fra 92-gruppen har briefet MPU - Folketingets miljø- og planlægningsudvalg - om status på klimaforhandlingerne. Det er dag 5 på COP15. Uden for mødelokalet huserer 15.000 mennesker i Bella Center. Om end der stadig er en uge til topmødets afslutning, er der krisestemning blandt dem, som følger forløbet tæt.

Få dage forinden, den 8. december, er en dansk forhandlingstekst blevet lækket til The Guardian. Teksten har skabt voldsom kritik fra ulande og ngo'er, der mener, at Danmark fører „uigennemskuelige“, „parallelle“ forhandlinger og tilgodeser USA. End ikke politikerne fra Christiansborg kan få besked om, hvad der foregår. Luften er tyk af konspirationsmetaforer og forsøg på at afdække ,spillet“: Hvad er ,røgslør“, ,rygter“, de ,reelle meldinger“, og hvad foregår der på og ikke mindst „,bag scenen“? Hvad er egentlig den danske forhandlingsstrategi?

At følge forhandlingerne på klimatopmødet i december 2009 rejste en lang række spørgsmål om, hvordan man kan bedrive antropologi i et politisk rum, tæt sammenvævet af utallige politiske interesser. Et rum, hvor den politiske proces er et galopperende udmattelses- og udskillelsesløb, hvor netværker og viden om forhandlingernes tekniske substans er altafgørende, hvor end ikke forhandlerne kan gennemskue alt, hvad der foregår. Og hvor grænserne mellem lokalt, nationalt og globalt, mellem statslige og ikke-statslige aktører, mellem politikere, embedsmænd, ngo'er og medier overskrides konstant. Om end „multivokalitet" og „multilokalitet“er gængse begreber, virkede klimatopmødets „,multi-ness“ næsten absurd i sin kompleksitet. Jeg vil her diskutere, hvordan man analytisk kan angribe den politiske proces og det politiske i et felt som COP15. 
Op til COP15 søgte jeg at „finde“ den politiske proces ved at følge den kakofoni af klimarøster, som indtog København, og ved at deltage i klima- og energiminister Connie Hedegaards utallige offentlige møder, velvidende at jeg var uendelig langt fra orkanens politiske øje. Om end jeg i de kommende måneder nærmede mig en form for politisk centrum, viste det sig, at denne søgen, stræben, suget efter at ramme orkanens øje, at være, hvor det sker, og vide, hvad der egentlig sker, var et helt fundamentalt forhold for de politiske aktører. Det $e r$ den politiske proces. At skaffe sig adgang til information om processen var en central del af processen, både for de ngo-lobbyister i 92-gruppen, jeg endte med at følge tæt, og for forhandlere og politikere.

Det er den politiske proces som en søgen efter viden gennem netværker og relationer, de konstante forsøg på at afdække rygter og røgslør, jeg her vil beskrive, og de konsekvenser, den proces har for en antropologisk tilgang til det politiske.

For det første vil jeg med afsæt i balladen omkring „den danske tekst“ understrege det metodisk brugbare $i$ at analysere dokumenters „,sociale liv“ og at følge de „nøglebegreber“, som de politiske konflikter samler sig omkring (Riles 2000; Shore \& Wright 1997). For det andet vil jeg analysere 92-gruppens relation til den danske delegation og diskutere, dels hvilken form for udveksling ngo'er og embedsmænd indgår i, dels hvilke ideer om det politiske ngo'ernes forhandlinger med delegationen og UNFCCC afspejler. ${ }^{1}$

\section{2-gruppen som base}

Før, under og efter COP15 deltog jeg i ngo-netværket 92-gruppen og deres møder med den danske delegation. I oktober mødte jeg John Nordbo, klimapolitisk bannerfører for WWF. Han havde for længst afvist at give et interview på grund af tidspres, men han sagde, at hvis jeg kom til Barcelona ugen efter, hvor de sidste UNFCCC-forhandlinger før COP15 fandt sted, ville han introducere mig til folk og forløbet, herunder 92-gruppen.

92-gruppen er en sammenslutning af danske udviklings- og miljøorganisationer og tæller de vigtigste klimalobbyister fra blandt andet Greenpeace, CARE, IWGIA, Nepenthes, Folkekirkens Nødhjælp, Det Økologiske Råd, Ibis og Mellemfolkeligt Samvirke. 92-gruppens klimapolicygruppe består af folk, der har års erfaring i klimaforhandlinger, og de har et særdeles veludviklet netværk både lokalt og globalt i kraft af deres respektive organisationers globale virke. Når jeg her refererer til ngo'er, er det derfor policylobbyisterne, jeg henviser til - de, som er placeret i det politiske maskinrum, og som opererede både på og „bag scenen“ i Bella Center - i modsætning til ngo'ernes aktivistdel, som afholdt 
demonstrationer uden for Bella Center, og hvis forhold til „systemet“ - den danske stat, forhandlerne, UNFCCC - er langt mere konfrontatorisk.

I klimaforhandlingerne udgør 92-gruppen den primære kontakt mellem ngo'erne og de danske ministerier. At deltage i deres interne strategimøder, deres møder med repræsentanter fra primært Klima- og Energiministeriet og deres løbende briefinger af pressen og politikere gav mig en unik mulighed for at iagttage, hvordan ngo'erne søger at få adgang til og indflydelse på den politiske beslutningsproces, og hvordan forholdet mellem ngo'er og ministerier forløber i en konstant udveksling af viden, netværker, relationer og dokumenter.

\section{Det politiske som felt}

Det var svært at afgrænse klimaforhandlingerne som felt i tid og rum. De tolv dage, COP15 stod på i Bella Center, var blot en kulmination på de UNFCCCforhandlinger, som er foregået over hele verden i årevis. For at forstå forhandlingerne på COP15 - både i de ,åbne“ rum, som ngo'er har adgang til, og de „lukkede“ forhandlinger og alt det, der foregår „,bag scenen“- var det ikke nok at være til stede på COP15. Det krævede års indsigt. De, som kunne gennemskue ,substansen“, havde været med i adskillige år, hvilket mildest talt sætter et feltarbejde på få måneder i relief. Det var derfor altafgørende, at jeg fik adgang til 92-gruppens møder, hvor forhandlingerne - som foregår parallelt i mange forskellige fora - blev diskuteret.

Det var så godt som umuligt at lave interviews med embedsmænd fra ministerierne - dels fordi de havde afsindig travlt, dels fordi de var bange for at udtale sig. Jeg lavede dog et par interviews med embedsmænd efter COP15 (som krævede fuld anonymitet). Men det var sigende for 92-gruppen, at de havde den privilegerede uformelle adgang til forhandlerne, som gav indsigt $i$, hvad der foregik bag linjerne. Journalisten Per Meilstrup, som senere skrev den fremragende bog Kampen om klimaet (2010), havde tilsvarende fulgt forhandlingerne i flere år og opbygget den fortrolighed, der gjorde ham i stand til at få interviews med de centrale spillere.

Snarere end at „konkurrere“ med dem, der havde den form for adgang, blev mit fokus rettet mod, hvordan de, der vidste, fik og spredte deres viden - med andre ord: hvordan forhandlingerne om viden om forhandlingerne foregik. Desuden var jeg optaget af, hvordan grænserne mellem de statslige og ikke-statslige aktører perforeres af den konstante udveksling af viden - samtidig med at den normative idé om to adskilte sfærer (stat vs. civilsamfund) til en vis grad opretholdes.

Ud over at jeg fulgte ngo-lobbyisternes vej gennem forhandlingerne, vil jeg understrege nødvendigheden af at lade felten formes af de nøglebegreber og 
dokumenter, som de politiske diskussioner drejer sig om. Både nøgleord (keywords) og dokumenter bevæger sig i tid og rum. Nøgleord akkumulerer og ,,mobiliserer“ betydning historisk, som Shore og Wright siger, og disse „semantiske skift“ er en form for „fingeraftryk“, der afslører „dybtgående transformationer i rationaliteter af governance“ (1997:19, min oversættelse). At følge de kontroverser og knopskydninger, der opstår omkring nøgleords betydninger, er et metodisk greb til at kortlægge, hvem der har ,magten til at definere“ de betydninger, hvordan og hvornår politisk forandring finder sted (op.cit.10). Det er én måde, hvorpå man kan afgrænse en ellers uafgrænselig felt og afdække konkurrerende lag af betydning.

Dokumenter er et centralt medium, hvorigennem politik praktiseres. Ligesom policies indeholder „samfundsmodeller“ og er et „charter for action“ (op.cit.7), afspejler og rummer dokumenter også en model for og konstruktioner af det politiske. Ved at analysere den lækkede „danske tekst“" og dokumentets ,sociale liv“ vil jeg senere belyse nogle af de konflikter, som omgav det danske formandskab på COP15 (Riles 2000, 2006). Men jeg vil også argumentere for, at de udbredte anklager om „,mistillid“, „uigennemsigtighed“ og ,skjulte forhandlinger“, der blev specielt tydelige i forbindelse med „den danske tekst“, afspejler specifikke idealforestillinger om det politiske - nemlig at det bør være gennemsigtigt, demokratisk og inkluderende.

\section{„Den politisk bindende aftale“}

Jeg fokuserede på nøglebegrebet en ,politisk bindende aftale“, som Statsministeriet lancerede i oktober 2009 som mål for COP15. Begrebet blev stærkt omdiskuteret. Ud over at lave interviews fulgte jeg begrebets semantiske sneboldeffekt - fra Lars Løkke Rasmussen præsenterede det på Christiansborg til en afsluttende forespørgselsdebat i Folketinget i januar 2010 - gennem samråd, pressemøder og -meddelelser, forespørgselsdebatter, spørgsmål til ministre, § 20-spørgsmål og mediedækningen.

Begrebet en ,politisk bindende aftale“ afspejlede en central konflikt omkring det danske COP-formandskab, hvor Statsministeriet (STM) og Klima- og Energiministeriet (Kemin) var dybt uenige om den rolle, Danmark skulle spille (jf. Kragh 2010). STM mente ikke, at det var realistisk at få en ny juridisk aftale på COP15 (selv om det var COP15's mandat), og opfandt derfor begrebet en ,politisk bindende aftale", der skulle sikre, at man i København fik nedfældet det, man trods alt kunne blive enige om, og som ville give Danmark en rolle lig den, vi havde under EU-topmødet i København i 2002. dvs. en mere udfarende position, hvor Danmark aktivt skulle skabe en „landingsbane“ for de stridende parter. 
Kemin med Connie Hedegaard i spidsen havde skaffet COP15 til København, kendte UNFCCC's procedurer og vidste, at det var nødvendigt for Danmark at være en neutral facilitator, der konsulterede bredt med i- og ulande. Både Kemin og ngo'erne var derfor uenige i STM's strategi. De klandrede Statsministeriet for at gå USA's ærinde, som ikke ønskede at binde sig juridisk, at sænke ambitionsniveauet og støde ulandene fra sig. Både den ,politisk bindende aftale“ og STM's forsøg på at køre sin egen dagsorden igennem, der ikke fulgte UNFCCC's spilleregler, anså ngo'erne for at være en ,satset dagsorden“. Det var netop den konflikt, som „den danske tekst“ synliggjorde. Men før jeg vender tilbage til den og til 92-gruppen, vil jeg umådelig kort opridse COP15's centrale spørgsmål.

\section{COP15 for dummies}

Målet for COP15 var at skabe en ny, global klimaaftale, der begrænser den globale opvarmning til 2 grader celsius (jf. IPCC 2007). En ny klimaaftale skulle efterfølge Kyoto-protokollen fra 1997, hvor en række ilande forpligtede sig til $\mathrm{CO}_{2}-$ reduktioner. Kyoto-protokollens første forpligtelsesperiode udløber i 2012.

Problemet er dels, at USA - verdens per capita største udleder af $\mathrm{CO}_{2}$ - aldrig ratificerede Kyoto og derfor ikke er pålagt nogen forpligtelser, hvilket både EU og ulandene finder dybt uretfærdigt. Dels er verdens store ulandsøkonomier som Indien, Kina og Brasilien ikke forpligtet til reduktioner under Kyoto, som blev indgået på baggrund af landenes ,historiske ansvar“, det vil sige, at de ilande, der har forurenet atmosfæren, også skal reducere mest $\mathrm{CO}_{2}$. Eftersom de store ulande fremover bliver store $\mathrm{CO}_{2}$-udledere - Kina er allerede totalt set verdens største udleder - kræver blandt andet USA og EU, hvis konkurrenceevne er på spil, at de også bliver pålagt reduktioner fremover. Men hvem skal flytte sig først - de ilande, som beviseligt har et historisk ansvar, eller de nye økonomier? Derudover diskuteres, hvor mange penge ulandene skal tilbydes i kompensation for deres udgifter til tilpasning og forebyggelse af klimaforandringer.

Siden 2007, hvor den såkaldte „Bali-køreplan“(„Bali Road Map“ eller „Bali Action Plan") blev vedtaget, har forhandlingerne kørt på to spor. Det ene spor omhandler en ,anden forpligtelsesperiode" for Kyoto-protokollen, hvor nye reduktionsmål for ilandene diskuteres (sporet hedder formelt AWG-KP, „Ad Hoc Working Group on Further Commitments for Annex I Parties under the Kyoto Protocol“", i daglig tale „KP-sporet“). En „,2 graders-målsætning“vil kræve, at ilandene reducerer deres $\mathrm{CO}_{2}$-udslip med 25-40 procent i 2020 i forhold til 1990.

Det andet spor (AWG-LCA, „Ad Hoc Working Group on Long-term Cooperative Action under the Convention“, i daglig tale „LCA-sporet") forhandler en løsning, der inkluderer alle lande, og behandler emner som reduktions- 
mål, finansiering, tilpasning, forebyggelse, kapacitetsopbygning, teknologi, skovrydning etc. Planen var, at både KP- og LCA-sporet skulle forhandles færdigt på COP15. Det skete ikke.

\section{Substansens kompleksitet}

Som det fremgår, er UNFCCC-forhandlingerne komplekse sager. „UNFCCCforhandlingerne er de mest komplekse i verden, fordi det er hele verden, man forsøger at ændre," som en ngo-lobbyist sagde. Forhandlingerne holdes i et meget teknisk sprog, der på den ene side opbygger social stratifikation og grænser - mellem de indviede, der besidder viden, og outsiders, der ikke gør - og som på den anden side nedbryder de institutionelle grænser mellem de forskellige slags aktører (medier, ngo'er, forhandlere).

På den daglige en-times-briefing mellem delegationen og ngo'erne var mængden af information mind-blowing. På den første briefing i Barcelona gennemgik embedsmanden Grønlands-dialogen, status på finansiering og forebyggelse, forholdet mellem finansiering og governance, forholdet mellem ,differentiated“ og „,common mitigation targets“, valget mellem ,schedules“ og „registre“ i forhold til udviklingslandenes nationale kommunikationer, rollen, som ,offsets“ skulle spille, forholdet mellem ministre og forhandlere og forhandlernes behov for politisk ,guidance“, behovet for at klargøre „upfront finance“, spørgsmålet om den ,politisk bindende aftale“ og mulige resultater i København.

De følgende dage inkluderede repertoiret diskussioner om de overliggende elementer på forebyggelse: forskellen mellem 1B1 og 1B2 i Bali Action Plan, hvorvidt NAMA'erne skulle være støttede eller ustøttede, forpligtende eller frivillige, hvorvidt der skulle være en ,matching mekanisme“ mellem finansiering og reduktioner, hvorvidt forhandlingerne ville være åbne eller lukkede, status på de cirkulerende „non-papers“, mulige skatter på „bunkers“, forskellige „,baselines“, „,compliance“mekanismer, bekymringer om KP'en og desuden spørgsmål vedrørende MRV, LULUCF, „range“ og „governance for funding“. Jeg nedfældede desperat den uvante lingo, mens jeg overvejede, hvilken planet jeg var landet på.

På UNFCCC's hjemmeside ligger en 13 siders oversigt med akronymer. ${ }^{2}$ Før man kan sine 13 siders forkortelser og som minimum kender indholdet, retorikken og knasterne i Bali Action Plan, Kyoto-protokollen og konventionen, er det i bedste fald omsonst at følge forhandlingerne. Som en af de garvede ngo'er sagde: „Det tog mig fire dage bare at blive i stand til at læse en dagsorden.“

At besidde den esoteriske viden om „substansen“" skaber et raffineret statushierarki blandt lobbyisterne, og det giver ngo'erne en platform at operere på. Der 
var i 92-gruppen jokes om, hvem der kunne sine forkortelser, og gruppen kunne nemt marginalisere de uindviede - eller uønskede - ved at tale i tilpas tekniske termer. Samtidig indgår de tekniske termer i et subtilt spil mellem ngo'erne og embedsmændene, hvor ngo'erne markerer, at de ikke blot kan fejes af, men kan stille krav om en diskussion af substansen. Omvendt følte selv visse repræsentanter fra ministerierne sig intimideret af ngo'ernes indsigt, og det var ikke kun ideologiske forskelle, men også forskelle i vidensniveau, der prægede de positioneringer.

\section{At skaffe sig adgang}

Da vi nåede til COP15, blev forhandlingernes kompleksitet yderligere kompliceret af det enorme opbud af mennesker, og spørgsmålet om at få adgang - til information og til stedet - blev endnu mere presserende. Dels var det et veritabelt forhindringsløb at få en akkreditering til Bella Center, dels havde UNFCCC klart undervurderet deltagerantallet, og selv når man fik sit adgangsbadge, tog det timer at komme ind. Bella Centers mangelfulde kapacitet betød også, at UNFCCC forsøgte at begrænse antallet af deltagere i COP'ens anden uge. Derefter startede kampen om at få adgang til de såkaldte „,secondary badges“: Hver organisation fik et begrænset antal badges, som de så skulle fordele blandt dem, som allerede var blevet akkrediteret.

De sidste to dage blev stort set samtlige ngo'er forment adgang - igen med begrundelsen om begrænset kapacitet. Lobby-ngo'erne har siden Kyoto-aftalen haft en særlig position i UNFCCC, hvor de har adgang til en række forhandlinger, som er lukkede for pressen (Depledge 2005). Den adgang er dog også hele tiden til forhandling og følger sine egne regler. (En regel, som blev overtrådt et par gange, er, at ngo'ernes lobbyisme og aktivisme holdes adskilt. Hvor ngo-området $\mathrm{og}$ forhallen med den store hvide globus og mediebroen, der skar gennem rummet, var hjemsted for mange finurlige ngo-optrin, var det strengt forbudt for ngo'erne at demonstrere inde i forhandlingslokalerne). Lobby-ngo'ernes ellers privilegerede position blev klart undergravet, da de blev udelukket på COP'ens sidste dage. Nok handlede det om stedets kapacitet, men i takt med at COP15 lignede en katastrofe, opfattede 92-gruppen det også som et forsøg på at kontrollere informationsstrømmen.

Jo mere komplekse og lukkede forhandlingerne blev, des mere påtrængende var behovet for information, og rygtebørsen florerede livligt. „Hvad er status? Er der overhovedet nogen, der ved, hvad der foregår?", som koordinatoren for 92-gruppen gentagne gange sagde, når gruppen mødtes i „førerbunkeren“ for at danne sig et overblik, lægge strategi og gennemskue, hvem der havde plantet 
hvilke historier i medierne. Ingen informationer blev taget for pålydende, og specielt tv-mediernes versioner virkede tit forvrængede, i grelle tilfælde helt ugenkendelige, set fra ngo'ernes position. „Forhandlingerne fortsætter i en venlig atmosfære" rapporterede TV Avisens Steffen Kretz på et tidspunkt, hvor 92-gruppen anså et sammenbrud for at være nært forestående. Folk rystede på hovedet: „Hvor har han været?!“

\section{På kanten af staten?}

At afklare „status“ på forhandlingerne var et helt centralt emne mellem 92-gruppen og den danske delegation, en relation, der var præget af gensidig afhængighed, udveksling og kritik. Ngo'erne søgte at ,udsætte“ ministerierne „for argumenter" og at mobilisere en moralsk horisont for handling (jf. Willetts 1996; Joachim \& Locher 2009). Embedsmænd og ngo'er indgik i en magtkamp, hvor 92-gruppen forsøgte at gennemhulle ministeriernes spin, men samtidig delte de ønsket om at „forstå processen“ og kvalificere forsøgene på at „læse i kaffegrums“, som én kaldte det.

Generelt set anses ngo'er for at være ikke-statslige aktører, som skal påvirke staten og være en „uafhængig“ vagthund. Den analytiske skelnen mellem stat og ikke-stat har selvsagt sit historiske ophav i udviklingen af demokrati i Vesten, som blandt andet skete gennem en mobilisering af et ,uafhængigt" civilsamfund. Men det er vigtigt at understrege, at den påvirkning også hele tiden går den anden vej, og at en skarp skelnen mellem stat og civilsamfund er analytisk ufrugtbar. Den pointe er blevet fremhævet i antropologiske studier af staten i udviklingslande (Hefner 1998; Hansen \& Stepputat 2001; Das \& Poole 2004; Sharma \& Gupta 2006; Christensen 2011), men den er lige så vigtig i en dansk klimapolitisk sammenhæng. UNFCCC er et transnationalt foretagende, som godt nok repræsenteres af stater (,parties“), men de perforeres af både lokale og globale interesseorganisationer. Grænserne mellem stat og civilsamfund var „blurred“, som Akhil Gupta kalder det, og determineret af personlige relationer (Gupta 1995).

Det kom helt an på den pågældende embedsmand i ministeriet, hvilken form for nærhed og udveksling der fandt sted i de daglige briefinger, og dermed, hvordan de legitime grænser mellem stat og civilsamfund blev defineret.

Som John Nordbo fra WWF sagde: „Vi er vant til, at det svinger meget fra person til person, om man får noget ud af det. Sommetider har man efter sådan en briefing [...] haft lyst til at gå ud og hamre hovedet ind i en mur og tænkt 'Hold kæft, hvor er I nogle idioter, altså. Lad nu være med at sidde og spilde vores og jeres tid på den her måde.' Og andre gange har man syntes, at man fik masser med hjem, som gav mening og var dybt, dybt fornuftigt at høre på, og somme- 
tider nogle deciderede redskaber i form af informationer om status på processer eller landes synspunkter, som er brugbare, så det har været meget varierende.“

I nogle tilfælde søgte ministerierne konkret råd hos ngo'erne. Det mest eklatante eksempel var, at Kemin kontaktede WWF for at få hjælp til den videre proces, da forhandlingerne torsdag nat den 17. december var brudt helt sammen. 92gruppen arbejder derfor også „bag scenen“ (Depledge 2005:219). De står ikke på ,kanten af staten“, som Das og Poole kalder det (2004), men opererer i de centrale maskinrum og er med til at reproducere staten (Navaro-Yashin 2002:165).

92-gruppen var derfor også afhængig af at have gode relationer til ministerierne, og selv om de var dybt frustrerede over STM's strategi, tog de en række hensyn i deres kritik for ikke at undergrave formandskabet totalt. De lavede en såkaldt „fire wall“" mellem Kemin og STM, hvor de dirigerede deres kritik af den „politisk bindende aftale“ og den lækkede tekst i retning af Statsministeriet, som havde ansvaret, men forsøgte at friholde Connie Hedegaard - som, de vidste, var helt uenig i den kurs - så hun trods alt kunne fungere som COP-formand. 92-gruppens „fire wall“" afspejlede på den ene side den balancegang mellem nærhed og distance, der skulle sikre deres indflydelse og legitimitet, og på den anden side gruppens placering i den åbenlyse konflikt mellem de to ministerier.

Som Søren Dyck-Madsen fra Det Økologiske Råd senere forklarede: „Klimaministeriet og ngo'erne havde en opfattelse af, at et eller andet sted henne var vi samarbejdspartnere, fordi vi havde samme dagsorden. Vi havde forskellige roller at spille, men slutmålet var ikke så forskelligt. [...] [Men] ngo'erne blev også spillet lidt af banen, da Statsministeriet overtog. [...] Den dagsorden, Statsministeriet kørte, var jo en, som ngo'erne ikke kunne acceptere. Lige pludselig havde man ikke samme mål, man havde ikke samme virkemidler, man havde ikke samme proces mere, som vi i meget højere grad havde med Klimaministeriet. [...] Det gav et voldsomt skift. Statsministeriet kunne man jo stort set ikke få møder med, men Klimaministeriet, dem kender vi jo og har været sammen med i ti år, også dengang, de var Miljøstyrelsen og Energistyrelsen osv., der var det jo stadigvæk de samme folk. Og det betyder meget, altså netvcerk og tillid mellem mennesker betyder utroligt meget i den her proces. Så det at være med over længere tid, og have et troværdigt image - at hvis man kommer med et eller andet, så er der nok noget om det, eller også har man hørt det et sted, som man kan stole på - det betyder enormt meget. Og der er Statsministeriet der ikke, og for Statsministeriet er ngo'erne der heller ikke.“

Som Dyck-Madsens beskrivelse understreger, bliver de personlige relationer og den gensidige tillid - eller mangel på samme - helt afgørende, når de institutionelle og formelle grænser mellem statslige og ikke-statslige aktører overskrides. 


\section{Dokumenters sociale liv: „Den danske tekst“}

COP15 udgjorde i sagens natur et politiseret felt af radikalt forskellige verdensbilleder og versioner af virkeligheden. Feltet var præget af det, Andrew Shryock kalder ,partisan multivocality“: antagonistiske ideologier, gensidige beskyldninger og „blame games“ (Shryock 1997:9). Det blev ikke mindst tydeligt i forbindelse med „den danske tekst“ og dens ,,sociale liv“. Teksten blev del af en konspirationslignende diskurs om „,uigennemsigtighed“og ,skjulte alliancer“, som først og fremmest afspejlede en konkret erfaret mistillid til det danske formandskab, men også i mere generel forstand reflekterer normative forestillinger om, hvordan den politiske proces burde vare - nemlig transparent og demokratisk.

92-gruppen diskuterede, om formandskabet ville fremlægge en dansk tekst, der kunne danne grundlag for et kompromis til sidst i forhandlingerne. „Danmark vil ikke lægge en tekst på bordet, “ sagde flere embedsmænd til ngo'erne før COP15. „De vil forhandle på baggrund af forhandlingsteksterne.“ Ngo'erne tvivlede på, at det var tilfældet, og det blev en stående joke mellem ngo'erne og embedsmændene at få fingre i den danske tekst. „Hvorfor giver I os ikke bare en kopi af den danske tekst“, ville 92-gruppen spørge, halvt i spøg, en del i alvor.

Ngo'ernes tvivl var blandt andet begrundet i, at de vidste, at versioner af en dansk tekst cirkulerede under forhandlingerne i Barcelona, og at ministerierne havde skændtes om både indholdet i teksten og de lande, som skulle konsulteres. Statsministeriet havde måneder før COP15 krævet at få et udkast til en mulig kompromisaftale, mens Klima- og Energiministeriet understregede, at det var umuligt at producere sådan en tekst uden at tage højde for, hvor langt forhandlingerne i UNFCCC's regi var nået til den tid (Meilstrup 2010:145-7). Set fra ngo'ernes og Kemins position var en kompromistekst, som ikke var baseret på de to forhandlingsspor, et risikabelt dokument, fordi Danmark i så fald ville blive kritiseret for at negligere FN's regler om åbenhed og konsensus.

Spillet omkring teksten flyttede fokus til hemmeligheden om den og forsøgene på at afsløre den hemmelighed. Det er en vigtig måde, det politiske ageres på. Udadtil blev embedsmændene ved med at forsikre ngo'erne om, at der ikke var nogen dansk tekst. Siden skiftede den officielle forklaring til, at der eksisterede mange forskellige tekster. På en pressekonference på COP15's første dag understregede Connie Hedegaard: „Der er ikke én tekst. Der cirkulerer mange forskellige tekster, men det udkast, som måske kan blive accepteret her i slutfasen, det vil først blive cirkuleret på et senere tidspunkt, og ingen kan have set det, for det er der ikke. For det bliver nødt til at reflektere det, der sker, det, som kan blive resultaterne fra AWG-LCA og KP“ (min oversættelse og kursivering). De mange afvisninger blev nærmest absurde, da „den danske tekst" næste dag, den 8. december, blev offentliggjort i The Guardian. Sa brød helvede løs. 


\section{Ngo'ernes respons}

At få adgang til dokumenter var del af 92-gruppens forhandling med ministeriet, men det var også led i et internt magtspil blandt ngo'erne. Selv om de samarbejdede, var der en subtil konkurrence om, hvem der fik adgang til de vigtigste dokumenter først. Begge dele eksemplificeres af en samtale på 92-gruppens interne møde, få timer før The Guardian offentliggjorde teksten:

Isabel (Ibis): 'Vi har fået at vide, at den er der.'

Troels (92-gruppen): 'Den bør sive inden længe.'

Poul Erik (CARE): 'Jeg har set adaptationsdelen.'

John (WWF): 'I bliver nødt til at lægge mærke til datoen på alting. Der er et skift fra Statsministeriet, som kun opererer med én tekst, til Kemin, som arbejder på flere dele og lægger ting ud til diskussion. De vil sige, at der er fem tekster.' Troels (92-gruppen): 'Det er svært at få adgang til viden om teksten. Vi er næsten for tæt på delegationen til at få den. Det er svært for embedsværket at udlevere teksten. Det var lettere, hvis det var den hollandske delegation.'

Jon (Greenpeace), efter en kunstpause og med et smørret smil: 'Vi har den samlede tekst, dateret den 27.11.'

Troels (92-gruppen), med et smil: '27. november?! I er forældede!'

Jon (Greenpeace), triumferende: 'Det er bedre end det, I har!'

Uvillig til at dele dokumentet med resten af gruppen gav Jon Burgwald (Greenpeace) et hurtigt opkog: „Det er værre, end vi frygtede. Alt undtagen finance er skidt. Der er et svagt sprog på de 2 grader. Adaptation står meget svagt. Der er ingen tidslinje for en juridisk aftale. Der står bare COPxx. Additionalitet er ude at svømme. Og short term finance vil blive brugt som salgsargument.“

Ifølge mine senere interviews havde både Greenpeace, WWF og Oxfam set teksten og om morgenen den 8. december diskuteret, hvorvidt de skulle lække det eller ej. Om end det var „,indlysende“, at det ville blive lækket, havde WWF været tilbageholdende, sagde John Nordbo. Det var en afvejning af på den ene side, hvorvidt en læk af den karakter ville underminere formandskabet fuldstændigt, og på den anden side nødvendigheden $\mathrm{i}$ at udstille det, de anså for at være Statsministeriets uacceptable dagsorden.

Som sagt arbejdede ngo'erne i høj grad også bag scenen. Men deres indflydelse fordrede både en nærhed og distance til magten: De var ,for tæt på delegationen" "til at fă den derfra, som Troels Dam Christensen (92-gruppen) sagde, det skulle ske via deres internationale netværk. I visse sammenhænge opretholder ngo'erne derfor en forestilling om og agerer, som om en adskillelse mellem stat og civilsamfund eksisterer, selv om de konstant søger indflydelse ved at overskride den grænse (jf. Navaro-Yashin 2002:179). 


\section{Kritikkens substans}

The Guardian publicerede teksten og beskrev ulandenes rasende respons. Kritikken gik dels på tekstens hemmelighedskræmmeri: Det danske formandskab kørte parallelle forhandlinger og drev FN-forhandlingerne ud på et sidespor. Dels på indholdet: Dokumentet ville - i modsætning til princippet om de rige landes historiske ansvar - pålægge ulandene $\mathrm{CO}_{2}$-reduktioner. Hvad værre var, om end teksten hævdede, at den „byggede på Kyoto-protokollen“, ville den de facto gøre Kyoto-protokollen overflødig (Vidal 2009).

Såvel form som indhold skabte ramaskrig blandt ulande og ngo'er, specielt på grund af den manglende reference til Kyoto-protokollen. „Der står ikke noget om KP'en. Hvis det her bliver godkendt, betyder det, at KP'ens regelsæt ikke går videre. De skriver, at den 'bygger på Kyoto-protokollen', men det betyder jo, at de afskaffer Kyoto-protokollen. Vi ved det jo!“" sagde John Nordbo på 92-gruppens møde og fastholdt at „Connie vil ikke forsvare det her“.

Lumumba Stanislaus Di-Aping, talsmanden for G77-landene (der tæller 130 ulande), indkaldte til en improviseret pressekonference, hvor han højrøstet kritiserede den danske statsministers „hemmelige dagsorden“. En gruppe afrikanere gennemførte en spontan demonstration i forhallen, hvor de hoppede, sang og skreg: „Afrika vil ikke dø i stilhed!“

\section{Eksisterer teksten?}

Selv da teksten stod skrevet sort på hvidt i The Guardian, fastholdt embedsmænd og pressechefen i Kemin, at en hemmelig dansk tekst ikke eksisterede. „Dette er under ingen omstændigheder Danmarks 'hemmelige udkast' til en ny klimaaftale. En sådan findes nemlig ikke" hedder det i pressemeddelelsen fra Kemin, som Berlingske Tidende videregav (Kolby \& Kragh 2009). Ifølge 92-gruppen lignede det „en officiel ikke-officiel forklaring“, som Kemin utvivlsomt havde plantet.

Desuden insisterede Kemin på, at der var en anden tekst, som faktisk forholdt sig til Kyoto-protokollen. „Det var kun ét blandt mange arbejdspapirer,“ sagde pressechefen. 92-gruppen følte sig dog ikke overbevist. „Der er altså for dårlig logik i den, “ sagde Troels Dam Christensen (92-gruppen). „I går sagde Kemin, at de ikke kender noget til det. Og i dag er det så den forklaring. "Og, som ngo'erne fremhævede, hvis et KP-papir fandtes, kunne de jo bare lægge det frem.

Annelise Riles, der har lavet feltarbejde på FN's kvindekonference i Beijing og blandt andet fokuserede på dokumenters rolle, siger: „I formelle sammenhænge [..] eksisterede et dokument ikke, hvis det ikke havde passeret gennem det korrekte netværks stier“ (2000:67, min oversættelse). Og specielt i henhold til FN's procedurer og respekten for de to forhandlingsspor havde dokumentet på ingen 
måde passeret de rette formelle kanaler. Tværtimod vidnede teksten om, som kritikerne hævdede, at Danmark havde skabt et „parallelt“ forhandlingsspor, hvor de kun havde konsulteret en kreds af få (primært i)lande.

Hvad jeg ikke vidste under COP15 var, at dokumentet i mere end en forstand ikke var gået gennem de rette kanaler. Ifølge Per Meilstrup var „den danske tekst“ en for Connie Hedegaard ukendt tekst. STM havde udarbejdet et dokument, der i Kemins optik var alt for ubalanceret og ilandsvenligt. En version, som Connie Hedegaard slet ikke var blevet forelagt, havde Statsministeriet udleveret til den amerikanske og kinesiske delegation før et møde i København den 1.-2. december (Meilstrup 2010:189f.). John Nordbo (WWF) havde med andre ord ganske ret i, at Kemin og STM arbejdede på forskellige tekster, og at „Connie ikke vil forsvare det her", for ud over at underkende ulandenes synspunkter marginaliserede teksten også hende. Den placerede COP15's formand i en aparte rolle som outsider i magtens koncentriske cirkler.

Selv om oppositionen i Folketinget formelt bad Statsministeriet fremlægge det ,andet“ arbejdspapir på KP-sporet, dukkede teksten aldrig op. Men måske var det ikke så overraskende. Under PreCOP'en den 16.-17. november havde Lars Løkke Rasmussen nøjedes med at kalde en fortsættelse af Kyoto-protokollen for en „mulighed“ (Rasmussen 2009).

Da jeg senere interviewede en højtstående embedsmand i Statsministeriet, sagde han om Kyoto-protokollen: „For mig giver en klimaaftale, der dækker nu 25 procent af verdens udledninger faldende til 20 over de næste ti år, ingen mening. Overhovedet. I forhold til 2 graders-målsætningen, som ligesom er den målsætning, vi alle arbejder med - det giver jo ingen mening. Det har ingen relevans." Meilstrup fremhæver dog, at Kemin faktisk havde udarbejdet et KP-papir, men på det tidspunkt havde Kemin mistet kontrollen.

\section{"Spillet omkring lækken“}

Den danske tekst var derfor ikke bare endnu en brik i magtkampen mellem STM og Kemin, den kørte reelt Kemin ud på et sidespor. Som John Nordbo (WWF) sagde efterfølgende:

Klima- og Energiministeriet ønskede jo ikke den der strategi på Kyoto-protokollen, de ønskede jo ikke, at [STM] opfinder en politisk bindende aftale, som de ikke rigtigt ved, hvad der er i. De forsøger [...] inden for de rammer, de har, at arbejde med det, men altså, det var jo ikke noget, de havde født, vel? Og det var heller ikke noget, de umiddelbart så den helt store logik i. Og hele måden omkring det danske papir, hvordan det kom til at flyde rundt i verden på et tidspunkt, hvor man har en beslutning i regeringens klimaudvalg om, at et dansk papir skal under ingen 
omstcendigheder sendes til andre i verden, så sender man det til amerikanerne. Fra Statsministeriets side af."

Ikke overraskende havde Statsministeriet en anden udlægning. Den højtstående embedsmand sagde:

Det var ikke lækken, der var problemet, fordi alle kendte jo teksten. Det var spillet omkring laekken, der blev et problem. Og så bliver det et selvstændigt problem, at især, vil jeg sige igen, de danske ngo'er, mere end de internationale, valgte så i virkeligheden ... Det var meget tankevækkende. Og jeg kom til at sige det til WWF meget, meget stærkt på et tidspunkt, fordi jeg var så forbløffet over det og også vred over det, om ikke de reflekterede over den alliance, de var endt i - Saudiarabien, Sudan, Venezuela, altså tre store carbonstater, som er kendt som ærkemodstandere af en klimaaftale, og så danske ngo'er. Det var de allerstærkeste kritikere af det, vi gjorde. [De] beskyldte os som COP-formand [for] at forråde en stærk klimaaftale.

Andre delte dog også den opfattelse. Den lækkede tekst ,ødelagde tilliden fuldstændig“, som Jairam Rameesh, Indiens miljøminister, senere sagde (Watts 2010). I forlængelse af den skepsis, som STM allerede havde skabt i løbet af efteråret med den i bedste fald uklare ,politisk bindende aftale“, blev den danske tekst „det dødsstød, som København aldrig overvandt“, som Connie Hedegaard senere erkendte (ibid.).

En af konsekvenserne blev, at Danmark fik utrolig svært ved at optræde som neutral mægler i COP'ens anden uge, hvor det måske havde givet mening at fremlægge en kompromistekst. På grund af den stærke skepsis - og fordi Lars Løkke Rasmussen lavede adskillige procedurefejl, da han overtog formandsstolen - nedlagde ulandene veto mod, at Danmark fremlagde en ny (og langt mere afbalanceret) tekst den 16. december. Danmarks evne til at agere som COP-vært var blevet væsentligt reduceret.

\section{Rygter og røgslør}

Spillet omkring ,den danske tekst“" og de rygter og røgslør, som i øvrigt florerede på COP15, kan ikke sidestilles med konspirationsteorier, som vi kender dem fra $X$-files, men de var udtryk for en beslægtet måde at forstå det politiske på. Det er den samme metaforik om „skjulte alliancer“, der opererer „bag scenen“. De samme afledningsmanøvrer, der følger forløbets fatale fejl. Konspirationsteorier er ikke blot en reproesentation af det politiske, de er udtryk for en oplevelse af det politiske, der udspringer af konkrete erfaringer, og som konstrueres i modsætning til en (lige så konstrueret) diskurs om transparens (Navaro-Yashin 2002: 182; Anderson 1996; West \& Sanders 2003:15; Fenster 2008). 
På COP15 afspejlede anklagerne i forbindelse med „den danske tekst“ dels et idealbillede om gennemsigtighed i de politiske processer, som prægede aktørernes forsøg på at skabe politisk handling. Dels var det udtryk for en konkret erfaret mistillid mellem parterne om, hvad „spillet“ gik ud på, og hvilke spilleregler der blev fulgt (eller ændret). Den lækkede tekst skabte så voldsom modstand, blandt andet fordi den viste, at nogen (én del af det danske COP-formandskab) forsøgte at kuppe en aftale igennem, som ekskluderede både Connie Hedegaard og en række ulandes retmæssige krav på indflydelse og tilsidesatte UNFCCC's to forhandlingsspor.

Ved at ville lave en ,politisk bindende aftale“ sammen med de „vigtigste“" statsog regeringschefer forsøgte STM at ændre reglerne fra UNFCCC's konsensusdemokrati til G8- eller G20-regler, hvor verden regeres af de mest magtfulde stater. STM mente reelt, at ,alt er til forhandling“, herunder også reglerne i UNFCCC. Som en højtstående embedsmand i Statsministeriet senere fortalte mig: „FN er jo et sted, hvor alt er til forhandling, det vil sige også rammerne og tidsfristerne og deadlines og strukturen og organiseringen af forhandlingerne." Det var UNFCCC, Kemin og en lang række ulande som sagt ikke enige i. Efterfølgende udtrykte selv Yvo de Boer, generalsekretær for UNFCCC, dyb frustration over Statsministeriets egenrådighed (Meilstrup 2010:291-4).

Rygterne på COP15 kunne have et fantastisk tilsnit, men det fantastiske viste sig ofte at ligge tættere på det faktiske, end man kunne tro. Allerede den første dag forlød det, at Connie Hedegaard ville sige op på grund af uenigheder med Statsministeriet, og om end „blot“ et rygte var det sigende for, hvordan Statsministeriets magtmanøvrer blev opfattet af dets kritikere.

Den 17. december, COP'ens næstsidste dag, gik der rygter om, at Mexico blev nødt til at overtage formandskabet fra Danmark før tid, fordi der var så stor mistillid til Lars Løkke Rasmussen. Rygtet forekom umiddelbart utroligt, men igen var det sigende for stemningen i Bella Center, og igen blev det på sin vis overgået af virkeligheden: Da Lars Løkke Rasmussen i timevis natten til lørdag havde forsøgt at mase den „Copenhagen Accord“ igennem i plenumsalen, som en lille gruppe lande havde besluttet (til stor forargelse for alle de lande, som i strid med FN's regler ikke var blevet hørt), og i øvrigt havde udstillet sin uvidenhed om UNFCCC's konsensusdemokrati ved at foreslå en afstemning, lykkedes det først at afslutte COP15, da Løkke overgav formandsstolen til Bahamas’ miljøminister.

\section{Konklusion}

Lækken af „,den danske tekst“" og de anklager om „parallelle forhandlinger“, som fulgte i tekstens kølvand, understreger, hvordan ideer om tilsløring og transpa- 
rens florerer på flere niveauer i den politiske proces: Som en bevidsthed om at bryde normen (det var faktisk Statsministeriets plan at indføre nye spilleregler i UNFCCC), som en bevidsthed om, hvornår de normer ikke kan brydes (,,vi er for tæt på delegationen til at få teksten“, som 92-gruppen sagde), som en idé om, at politik ikke „normalt" er sådan (de utallige henvisninger til, at det her bare er „spillet“, selv om „spillet jo er virkeligheden her“, ifølge Vestager), og som de utallige, gensidige beskyldninger om at agere uigennemsigtigt og bryde normen (Statsministeriet, der anklager ngo'erne for at iværksætte et ødelæggende „,spil omkring lækken“; Ngo'erne, der beskylder STM for at undergrave processen ved at føre parallelle forhandlinger).

Aktørerne forsøgte at afsløre „uigennemsigtighed“, „skjulte alliancer“ og „spillet“ som en undtagelsestilstand fra det normale. COP15's rygter og røgslør er derfor ikke blot en interessant indgangsvinkel til at belyse de konkrete erfaringer, der skaber mistillid og beskyldninger, og de spil, der eksisterer på og bag scenen, som ngo'erne tager livligt del i. De anskueliggør også aktørernes ideer om det politiske, herunder deres idealforestillinger om, hvordan det politiske burde være.

Den udveksling, som fandt sted mellem ngo'er og ministerier, viser, i hvor høj grad relationerne mellem aktørerne er præget af gensidig afhængighed, og hvor central en rolle ngo'er spiller i den politiske beslutningsproces. Men samtidig med at den politiske proces bestod af perforeringer og „,blurred boundaries“ (Gupta 1995) mellem ngo'er og forhandlere, reproducerer de politiske aktører også forestillingen om det politiske som ideal: De agerer, som om politik var transparent, som om stat og civilsamfund var adskilte enheder, og som om politik ikke afhang af personlige relationer og netværk (jf. Navaro-Yashin 2002:179).

COP15 var en så kompleks begivenhed, at man som antropolog ikke bare kunne placere sig ét sted for at forstå forhandlingerne. Ofte var forhandlingslokalerne det sted, hvor der foregik allermindst (i et tilfælde overværede jeg en 40 minutters debat om formuleringen af én sætning), og i stedet rendte man rundt som én blandt 15.000 andre hovedløse høns eller stod i alenlange køer for at købe mad, kaffe eller komme ind i Bella Center (køerne havde den fordel, at man stod der sammen med nogen, som man så kunne udveksle informationer med). Ud over at alliere mig med 92-gruppen og følge deres lobbyarbejde har jeg her fremhævet det brugbare $i$ at følge nøglebegreber og dokumenter og deres akkumulation af betydning både før, under og efter en begivenhed som COP15 for at kortlægge den politiske proces' „partisan multivocality“ (Shryock 1997:9).

De indsigter, et feltarbejde i det politiske giver, kan i høj grad overføres til andre sammenhænge. Feltarbejdet som et mellemværende blandt mennesker, der gør noget - hvad den handling end går ud på - er stadig helt afgørende, men nok 
så vigtigt er det at finde en systematisk måde at forholde sig til alle de andre informationer og diskussioner på, som felten udgøres af, og som ofte trækker lange historiske spor i både informationsstrøm og personlige relationer.

\section{Noter}

1. UNFCCC er en forkortelse for United Nations Framework Convention on Climate Change. Se www.unfccc.org.

2. „Glossary of climate change acronyms“. http://unfccc.int/essential background/glossary/items/ 3666.php.

\section{Litteratur}

Anderson, Jon W.

1996 Conspiracy Theories, Premature Entextualization, and Popular Political Analysis.

Arab Studies Journal IV(1):96-102.

Christensen, Janne Bjerre

2011 Drugs, Deviancy and Democracy in Iran: The Interaction of State and Civil Society. London \& New York: I.B. Tauris.

Das Veena \& Deborah Poole (eds.)

2004 Anthropology in the Margins of the State. Santa Fe: School of American Research Press.

Depledge, Joanne

2005 The Organization of Global Negotiations. Constructing the Climate Regime.

London: Earthscan.

Fenster, Mark

2008 Conspiracy, Secrecy and Power in American Culture. Minneapolis: University of Minnesota Press.

Gupta, Akhil

1995 Blurred Boundaries: The Discourse of Corruption, the Culture of Politics, and the Imagined State. American Ethnologist 22(3):375-402.

Hansen, Thomas Blom \& Finn Stepputat (eds.)

$2001 \quad$ States of Imagination. Ethnographic Explorations of the Postcolonial State.

Durham \& London: Duke University Press.

Hefner, Robert W. (ed.)

1998 Democratic Civility. The History and Cross-Cultural Possibility of a Modern

Political Ideal. New Brunswick \& London: Transaction Publishers.

IPCC, International Panel on Climate Change

2007 Climate Change 2007: Impacts, Adaptation and Vulnerability.

Cambridge: Cambridge University Press.

Joachim, Jutta M. \& Birgit Locher (eds.)

2009 Transnational Activism in the UN and the EU. A Comparative Study.

London \& New York: Routledge. 
Kolby, Mads \& Claus Kragh

2009 U-lande raser over dansk klimaudkast. Berlingske Tidende, 8. december.

Kragh, Anne Sofie

$2010 \quad$ Good Cop, Bad Cop. Euroman 195.

Meilstrup, Per

$2010 \quad$ Kampen om klimaet. Historien om et topmøde, der løb løbsk.

København: People's Press.

Navaro-Yashin, Yael

2002 Faces of the State. Secularism and Public Life in Turkey. Princeton \& Oxford:

Princeton University Press.

Rasmussen, Lars Løkke

2009 Pre-COP Consultations Copenhagen, 17 November. Address by Danish Prime Minister Lars Løkke Rasmussen. Statsministeriet. www.stm.dk/Index/ mainstart.asp/_pp_12991.html.

Riles, Annelise

2000 The Network Inside Out. Ann Arbor: The University of Michigan Press.

Riles, Annelise (ed.)

2006 Documents. Artifacts of Modern Knowledge. Ann Arbor: University of Michigan Press.

Sharma, Aradhana \& Akhil Gupta (eds.)

2006 The Anthropology of the State. A Reader. Malden, Oxford \& Carlton:

Blackwell Publishing.

Shore, Cris \& Susan Wright (eds.)

1997 Anthropology of Policy. London \& New York: Routledge.

Shryock, Andrew

$1997 \quad$ Nationalism and the Genealogical Imagination. Oral History and Textual Authority in Tribal Jordan. Berkeley, London \& Los Angeles: California University Pres.

Vidal, John

2009 Copenhagen Climate Summit in Disarray after 'Danish Text' Leak. The Guardian, 8. december.

Watts, Jonathan

2010 Copenhagen Destroyed by Danish Draft Leak, Says India’s Environment Minister. The Guardian, 12. april.

West, Harry G. \& Todd Sanders

2003 Power Revealed and Concealed in the New World Order. I: H.G. West \&

T. Sanders (eds.): Transparency and Conspiracy. Ethnographies of Suspicion in the New World Order. Durham \& London: Duke University Press.

Willetts, Peter (ed.)

1996 The Conscience of the World. The Influence of Non-governmental Organisations in the UN System. Washington: The Brookings Institution. 